\title{
A Fair Value Model for Bearer Biological Assets in Promoting Corporate Governance: A Proposal
}

\author{
Kamaruzzaman Muhammad \\ Faculty of Accountancy, Universiti Teknologi MARA, Malaysia \\ Erlane K Ghani \\ Faculty of Accountancy, Universiti Teknologi MARA, Malaysia
}

Received: October 7, 2013 Accepted: October 21, 2013

doi:10.5296/jas.v2i1.4630ＵRL: http://dx.doi.org/10.5296/jas.v2i1.4630

\begin{abstract}
This paper discusses IAS 41 Agriculture with specific focus on accounting for bearer biological assets in Malaysia. It presents the concerns raised by various parties on the applicability of IAS 41 on bearer biological assets particularly on the use of present value of future net cash flows model to determine the fair value of certain category of biological assets. This paper posits that there is a way to develop a fair value model through identifying factors that influence the fair value of bearer biological assets. The results of the proposed study would hopefully assist in the development of an alternative fair value model in valuing bearer biological assets and subsequently lead to good corporate governance specifically on the improving the qualitative characteristic of financial information.
\end{abstract}

Keywords: IAS 41, Agriculture, Bearer biological assets, Fair value, Corporate governance, Malaysia

\section{Introduction}

Agriculture industry has long been known to have a place in the economic development due to its nature of demand for agricultural commodities and nature of inputs (Lloyd and Malcolm, 1997). Within this industry, a range of commodities exist consisting from animals to plants for food and their produce or material. These animals and plants are highly influenced by their nature and geographical factors and therefore from the accounting perspectives, need to be valued independently rather than valuing as a whole (Thurrun Bakir, 2010). Similar with other countries, Malaysia has also placed a great importance on the agriculture industry to its 
economy particularly, plantations and forestry.

The increasing relevance of fair value as measurement as opposed to the historical cost has received serious attention from the main accounting standard setting bodies. This is evident by the recent standard's amendments and issues that demand the importance of certain fair value's elements. The lack of attention given by relevant parties to the agricultural activity has led to the increasingly demanding harmonisation of this industry. In realisation to this situation, the International Accounting Standard Body (IASB) has issued IAS 41 Agriculture which specifically addresses the fair value measurement of biological assets and agricultural goods (Azevedo, 2007).

Previously, plantation companies in Malaysia report their biological assets in the financial statements in accordance to Malaysian Accounting Standards Board (MASB) Standards, the Companies Act 1965, the Securities Commission's guidelines and the Bursa Malaysia's listing requirements (Tan, 2010). These plantation companies disclose biological assets, separately on the face of statement of financial position (Thurrun Bhakir, 2010) following the requirement of FRS 101 - Presentation of Financial Statements and measure the biological assets in accordance to Malaysian Accounting Standard (MAS) 8 - Accounting for Pre-cropping costs. MAS 8 has identified two common methods in accounting and reporting of biological assets namely, the amortisation method as the benchmark treatment for pre-cropping costs and capital maintenance method has been included in the standard as an allowed alternative treatment (MASB, 2006).

The introduction of International Financial Reporting Standards (IFRS) framework by International Accounting Standards Board (IASB) has led certain countries including Malaysia to adopt the same standards in attempt to increase harmonisation in accounting presentation and disclosure. Under this framework, biological assets are categorised into consumable biological asset which is to be accounted within the scope of IAS 41 Agriculture and bearer biological asset which is to be accounted under the scope of IAS 16 Property plant and equipment. Under IAS 41 Agriculture, the consumable biological asset such as trees in a timber plantation shall be measured on initial recognition and at the end of each reporting period at its fair value less costs to sell, which often can be determined by the existence of market value. For bearer biological asset such palm trees, this type of asset is required to be measured at its cost less any accumulated depreciation and any accumulated impairment loss under IAS 16 Property plant and equipment. The standard also requires the fair value of the bearer biological assets to be disclosed in the notes to the financial statements ${ }^{1}$. However, the determination of fair value of bearer biological asset is not easily determined due to the absence of market value.

One however, could pose a question. Does fair value benefits the users of accounting reports and if yes, what would be the best fair value model to be used in determining the fair value of bearer biological assets? This is because the requirement of fair valuing bearer biological assets that have no market value may encourage plantation companies to value their bearer biological assets based on assumptions of which could be subjected to manipulation. Of consequence, the

\footnotetext{
${ }^{1}$ As per September 2013, the revised IAS 41 Agriculture and IAS 16 Property plant and equipment issued by IASB are still under review as Exposure Draft.
} 
meeting the qualitative characteristic of useful financial information such as comparability and verifiability would be jeopardised which subsequently affect the good corporate governance practices among plantation companies. This argument is consistent with studies that show financial statement preparers are concern on the reliability of income recognition under fair value measurement of bearer biological asset due to the lack of active market particularly in the plantation and forestry sectors (Elad and Herbohn, 2011). Fisher et al. (2010) argue that such concern may reduce over time when the financial statement preparers fully understand the concept of IAS 41 Agriculture. Therefore, the adoption of fair value model on bearer biological assets is possible provided there is one fair value model that is reasonably reliable in determining the fair value of bearer biological assets. However, as to this date, there has yet to be a uniform fair valuation model for biological assets which could be attributed by the absence of the need to have such model until IAS 41 was introduced.

This paper proposes a study to examine the link between fair value accounting and agriculture with specific focus on bearer biological assets and consequently, develop a model of fair value for bearer biological assets. Specifically, the proposed study aims to identify the factors that influence the fair value of bearer biological assets which includes identifying factors such as age, species, locality and natural risks that affect fair valuation of bearer biological assets.

The remainder of this paper is structured as follows. The next section, Section 2 explains the measurement of bearer biological assets. This is followed by Section 3 that provides explanation on the issues on measurement of bearer biological assets. Section 4 provides a review of the relevant literature. Section 5 outlines the proposed research design. The contribution of the proposed study is provided in the last section.

\section{The Measurement of Biological Assets}

Before 2012, the plantation companies in Malaysia measure the biological asset in the financial statement in accordance with Malaysian Accounting Standard (MAS) 8-Accounting for Pre-cropping costs. MAS 8 define pre-cropping costs as expenditure on new planting or replanting of crops prior to their maturity. These costs include expenditures incurred on land preparation, roads, drains, plants, planting, fertilisation, irrigation and labour. New planting cost is defined as pre-cropping costs incurred in planting in an area which is not previously cultivated or in an area previously cultivated with different crops. Replanting cost on the other hand refers to pre-cropping costs incurred in replanting in an area which previously cultivated as a plantation with the same crops. The standard has identified two common methods in accounting and reporting of biological assets namely, the amortisation method as the benchmark treatment for pre-cropping costs and capital maintenance method has been included in the standard as an allowed alternative treatment (MASB, 2006).

Under amortisation method, the cost on new planting and replanting of biological assets are capitalised and once the biological assets reach maturity, the cost of the biological assets is amortised on a systematic basis over the useful life and charged to the income statement. Any subsequent maintenance cost throughout the harvesting period is also charged to the income statement. On the other hand, the capital maintenance method requires new planting costs to be capitalised and carried as a permanent item on the balance sheet and not amortised. This cost 
can only be charged to income once the asset is disposed. The cost on the replanting the crops are written off to income statement when incurred and considered as a substitute for amortisation. The amortisation method is better in the sense that it conforms to IAS 16 that reflects more accurately match the income with the historical cost and therefore is recommended as the preferred method to account for biological assets (MASB, 2006). Under the capital maintenance method, income is being matched with replacement costs or replanting cost.

In the effort of full convergence with International Financial Reporting Standards (IFRS), MASB has published Malaysian Financial Reporting Standards (MFRS) in 2012 which provides plantation companies to measure their biological assets either in accordance to MAS 8 Accounting for Pre-cropping costs or IAS 41 Agriculture until 2014. This option is given because issues in adopting IAS 41 Agriculture in Malaysian context have yet to be resolved and finalised. Upon finalisation, all plantation companies are expected to measure their consumable biological assets under IAS 41 Agriculture which is to be measured at fair value less costs to sell and bearer biological assets to be measure at cost less any accumulated depreciation and any accumulated impairment losses under IAS 16 Property plant and equipment.

\section{Issues on Measurement of Bearer Biological Assets}

Under the current IAS 41 Agriculture, all biological assets should be measured at fair value less estimated cost to sale at initial recognition and at subsequent reporting date. Under the revised IAS 41 Agriculture, it is expected only consumable biological asset to be measured at fair value less estimated cost to sell. On the other hand, bearer biological asset is expected to be measured at cost less accumulated depreciation and accumulated impairment losses under IAS 16 Property plant and equipment with additional information regarding fair value in the notes to financial statements. However, the financial statements preparers may face problems in disclosing the fair value of bearer biological assets in the notes to financial statements based on issues raised by previous studies. The issues that have been raised are: i. fair value of bearer biological assets cannot be easily determined due to in absent of market and difficulty in identifying the attributes of bearer biological assets. ii. cost to be incurred in the determination of fair value outweighs the benefit and iii. earning volatility and misleading and iv. lack of relevant information and knowledge related to the measurement of bearer biological asset (Foo, 2006; Thurrun Bhakir, 2010; Aryanto, 2010).

Proponents of fair value accounting note that fair value would better present the usefulness and transparency of information due to timely reflection of current market value (Laux and Leuz, 2009). The opponents of fair value accounting on the other hand, argue that fair value comes at the expense of reliability since fair value must be established using valuation techniques that require assumptions (Penman, 2007; Benston, 2008). Concerns have also been raised on the ascertainment of fair value for certain category of biological asset. For the biological asset which is bearer in nature and has long life cycle, it is difficult to determine its fair value due to the non-availability of an active market (Fargher, 2001; Elad, 2004). This is consistent with Thurrun Bakir (2010) that notes the difficulty in determining the quoted market price of bearer 
biological assets due to their non-tradable nature.

IAS 41 provides ways in identifying fair value of biological assets. One way is to determine the existence of an active market for the biological assets. If there is an active market for the biological assets, then the fair value should be based on the quoted market price. The standard also noted that there is a biological asset that can be traded in more than one market. In this case, the quoted price in the most relevant market should be used to determine fair value. On the other hand, if there is no active market of the biological asset, then the fair value should be the latest market transaction price or market price of a similar biological asset. If there is no market price and transaction price, then the fair value should be determined by the Discounted Cash Flow (DCF) method where the fair value is determine based on estimated net cash flow discounted at a pre-determine rate (IASC, 2001). The implementation of IAS 41 however is not easy particularly in the situation when the only DCF method to be used in valuing the biological assets such as bearer biological asset (Thurrun Bakir, 2010). However, using DCF method to determine the fair value of bearer biological assets has raised few issues.

The first issue concerns with the assumptions used in DCF method. The assumptions are often determined by the accountants or consultants and understandably, assumptions would likely to vary between companies and between countries. Due to this, the DCF method is inherently subjective and may provide opportunities for manipulation (Dvorakova, 2006; Thurrun Bakir, 2010).

The second issue relates to the use of DCF method is using different discounted rate in calculating present of value of future net cash flows. The discounted rate normally used is either pre-tax discount rate; pre-tax weighted average cost of capital or current market determined post-tax discount rate. Again, different companies will use different discounted rate and raised issues such as comparability and verifiability of financial statements between companies and countries (Dvorakova, 2006; Aryanto, 2010; Thurrun Bakir, 2010). In normal circumstance, the discount rate would be based on: i. the liquid nature of plantations prior to maturity, ii. lack of market evidence as to the value of forest plantations midway through their life cycle and adoption of a conservative valuation approach (Fisher et al., 2010). Therefore, arguably, the fair value determined by the DCF method may not reflect the true fair value of the bearer biological assets.

In sum, the use of DCF method to determine fair value of bearer biological assets has raised concerns on its appropriateness measurement system for fair valuing bearer biological assets. One likely alternative for a company to determine the fair value of bearer biological assets is by seeking a consultant to value their biological assets although this may lead the company to incur financial burden (MPOB, 2010). However, often consultants used similar mechanism in valuing bearer biological assets in which they used projected cash flow. Therefore, there is a need to develop a model that reflects a better representation of the fair value of bearer biological assets at the reporting model which ultimately, would benefit all stakeholders and promotes better corporate governance within the plantation companies.

This study posits a way to develop a fair value model through identifying factors that influence the fair value of bearer biological assets. The development of the model would ease the 
preparer and assists users of the financial statements in better understanding the factors that determine the value of bearer biological assets and subsequently enhance the qualitative characteristic of useful financial information. This would ultimately lead to good corporate governance practices among plantation companies.

\section{Literature Review}

The recent extension of fair value accounting has shifted the focus from financial instrument to agriculture sector due to the introduction of IAS 41. This has led several researchers to conduct studies on the link between fair value accounting and agriculture by examining the impact of fair value accounting in the agriculture sector (such as Elad, 2004; Fisher, Motersen and Webber, 2010; Elad and Herbohn, 2011). These studies have focused on examining few issues such as harmonisation of fair value methods (Dvorakova, 2006; Thurrun Bakir, 2010), factors influencing firms' knowledge on IAS 41 (Azevedo, 2007) and factors influencing fair valuation of agriculture (Staltmane, 2010).

In the context of developing country, there are not many studies that have examined the link between fair value accounting and agriculture. One reason to such lack of study could be due to the absence of the implementation of IAS 41 in developing countries. Only recently, researchers in the developing countries have started to examine this issue. For example: Aryanto (2010) examined this issue by way of content analysis on the theoretical aspects of IAS 41 and found that there is a rejection of IAS 41 due to volatility of earning and misleading on taxation-related decision. He argued that IAS 41 in developing countries failed to achieve comparability function of the financial statements. He concluded that there is a need to clarify the accuracy of the concept under IAS 41. Aryanto's study however was conducted in Indonesian setting.

A recent study by Thurrun Bakir (2010) has made an attempt to provide empirical evidence on this issue by examining the method used by Malaysian plantation companies in valuing their biological assets and identifying the readiness of these firms in adopting IAS 41. Using content analysis on 43 oil palm plantation entities listed on the Bursa Malaysia, he found that only 10 percent of the companies adopt fair value method. He also found that the companies having difficulty in identifying the attributes of biological asset and consider the valuation process of biological asset at balance sheet date as costly and burdensome. He argued that more work needs to be expensed to ensure the readiness of these firms in adopting IAS 41. Apart from Thurrun Bakir's empirical study, study examining the link between fair value accounting and agriculture is under-researched.

One study which is of interest to this study is a study conducted by Staltmane (2010) that examined whether factors affect the valuation of biological assets. He examined this issue due to his concern on the use of discounted cash flow method in fair valuing biological assets. He argued that such method does not represent a truer fair value of biological assets. Using a Latvian setting, he examined the effect of factors such as climate, disease and natural risk on the fair value of forestry and found these factors to influence the valuation of forestry. However, apart from Staltmane's study, there is yet a study that extends Staltmane's study and examines this issue. The exclusion of such examination provides a gap in knowledge on the impact of 
factors on fair value of biological assets. Following Staltmane's study, the proposed study will also examine the factors influencing the fair value of biological assets. Examining this issue will provide a truer method of valuing biological assets as opposed to the present value of future cash flows model.

\section{Proposed Research Design}

\section{The Setting}

The proposed study will use the palm oil industry as the research setting. This setting is chosen because Malaysia has placed a great importance on the agricultural industry to its economy particularly, plantations. Oil palm plantations play a significant role in the Malaysian economy. The palm oil commodity has expanded rigorously to become the largest income contributor to the country and in 1966, Malaysia took over Nigeria as the world's leading exporter and producer of palm oil (Khera, 1976; Rasiah and Abdul Rahim, 2006). The country accounts for about half of the world production of palm oil and its plantations, processors and manufacturers are regarded as the industry's technological frontier operator (Rasiah and Abdul Rahim, 2006). At present, Malaysia is the second largest producer and exporter of palm oil in the world (MPOB, 2010).

\section{The Sample}

The proposed study will use chief executive officers, accountants and estate managers attached in the plantation companies that have bearer biological asset in Malaysia as the respondents. These respondents must have experience and/or involved in reporting agriculture land and/ or biological asset in the financial statements. The choice of such respondents is because of their knowledge, experience and expertise in this area and therefore, they are considered appropriate resources in getting information required. This is consistent with Stalmane (2010) that argued that these people are appropriate candidates to evaluate the biological assets.

In order to provide a more comprehensive result, the proposed study will also use professional valuers. Professional valuers are chosen as the sample study since they have vast experience in valuation, and selling and disposal of land and most likely would have experiences in valuing land that has bearer biological assets. The proposed study will select professional valuers located in the Klang Valley, Malaysia. Apart from interviewing the professional valuers, valuation reports from the professional valuers will also be used in order to gain further understanding on fair valuation of bearer biological assets.

Auditors will also be approached in the proposed study to participate as respondents. These respondents would have been exposed to many ways in valuing bearer biological assets among the plantation companies in the event of performing their audit tasks. Therefore, they would have the experience and ability to identify potential factors that could influence the valuation of bearer biological assets.

Finally, the proposed study will approached representatives from MASB and National Institute of Valuations (INSPEN) as the sample study. Representatives from MASB are chosen as they have knowledge and experiences in dealing with accounting for agriculture and have been 
involved in the process of incorporating IAS 41 into the Malaysian Accounting Framework. Likewise, representatives from INSPEN are chosen as they have knowledge and experiences in valuation of land and their monitoring role on the professional valuers in Malaysia. Therefore, such representatives would be able to provide further understanding on the factors that influence the valuation of bearer biological assets.

\section{Research Instrument and Data Collection}

The proposed study aims to achieve the objectives by way of semi-structure interviews and content analyses. The interviews will be designed to ascertain the respondents' opinions on the factors that may influence fair valuation of bearer biological assets. In addition, a content analysis of the professional valuation reports will be performed. Finally, a content analysis will also be performed on the valuation reports obtained from the professional valuers to determine the factors that were taken into account in determining the fair value of bearer biological assets.

The analysis of the data obtained from the semi-structure interviews will be analysed using NVivo and content analysis will be performed using Statistical Package for Social Sciences (SPSS). The data will be coded and analysed accordingly. Table 1 presents the data collection phases of this study.

Table 1. Data Collection Phases

\begin{tabular}{|l|l|l|}
\hline Phase & Task & Description \\
\hline One & $\begin{array}{l}\text { Interview } \\
\text { session }\end{array}$ & $\begin{array}{l}\text { To obtain possible factors that could determine the fair valuation of biological assets } \\
\text { from preparers of agricultural companies and professional valuers. }\end{array}$ \\
\hline Two & Content analysis & $\begin{array}{l}\text { To obtain possible factors that could determine the fair valuation of biological assets } \\
\text { from the agricultural companies and valuation reports. }\end{array}$ \\
\hline Three & Data Analysis & To obtain results from the interviews and content analysis. \\
\hline Four & $\begin{array}{l}\text { Model } \\
\text { Development }\end{array}$ & To design a model of fair valuation of biological assets. \\
\hline
\end{tabular}

\section{Contribution of Proposed Study}

The proposed study will have few contributions. First, the findings of this study would assist the financial statement preparers to comply with the requirement in IAS 16 Property plant and equipment in order to disclose fair value of bearer biological assets in the notes to the financial statements. This can be done through the development of a fair value model that is more appropriate in establishing the fair value of biological assets. The development of this model would promote comparability and consistency in the determination of fair value of the bearer biological assets among plantation companies. Ultimately, the model would assist in achieving good corporate governance practices among the plantation companies in Malaysia. This paper will propose a fair valuation model using a multiple regression model based on the following:

$$
\mathrm{Y}=\mathrm{a}+\mathrm{B}_{1}+B_{2}+\mathrm{B}_{3}+\ldots \ldots .+\mathrm{B} x
$$


Where:

Y represents the fair value of the biological asset

B represents the predictor variables

Secondly, the development of a fair value model would allow the financial statement preparers to use a model in determining the fair value of bearer biological assets. Without the fair value model, the financial statement preparers may have to engage a professional valuer to assist them in valuing their bearer biological assets. Often, such engagement would involve high engagement cost which could become a burden to the companies. Therefore, the availability of a fair value model could alleviate the burden of engaging professional valuers to perform the task of valuing bearer biological assets.

In summary, the findings of the proposed study will provide an alternative or improvement to the existing measurement method of bearer biological assets. The fair value model developed could enhance qualitative characteristics of useful financial information related to fair value bearer biological asset. This in turn would promote good corporate governance practices among the plantation companies in Malaysia. This paper also provides some knowledge on the fair value accounting of bearer biological assets and such understanding would benefits the companies, statement preparers, statement users and the standard setters on the fair valuation of bearer biological assets.

\section{References}

Argiles, J. M., Blandon, J. G., \& Monllau, T. (2009). Fair Value and Historic Cost Accounting of Biological Assets, Working Papers in Economics, University of Barcelona, Spain.

Aryanto, Y. H. (2010). Theoretical Failure of IAS 41: Agriculture, The Indonesian Institute of Accountants, Available at: http://ssrn.com/abstract=1808413.

Azevedo, G. M. C. (2007). The Impact of International Accounting Standard 41 'Agriculture' in the Wine Industry Available at SSRN: http://ssrn.com/abstract=975508.

Benston, G. J. (2008). The Shortcomings of Fair-Value Accounting Described in SFAS157, Journal of Accounting and Public Policy, 27, 101-114. http://dx.doi.org/10.1016/j.jaccpubpol.2008.01.001

Burnside, A., \& Schiller, S. (2005). IAS 41 and the Forest Industry - A Study of the Forest Products Companies' Perception of the IAS 41 Today, School of Economics and Commercial Law, Goteborg University.

Dutt, S. (2009). IFRS Convergence Update (Malaysia), IFRS Conference: Seoul, 29 July.

Dvorakova, D. (2006). Application of Fair Value Measurement Model in IAS 41 - Relation Between Fair Value Measurement Model and Income Statement Structure, University of Economic, Prague, W. Churchill, Czech Republic.

Elad, C. (2004). Fair Value Accounting in the Agricultural Sector: Some Implication for International Accounting Harmonization, European Accounting Review, 13(4), 621-644. 
http://dx.doi.org/10.1080/0963818042000216839

Elad, C., \& Herbohn, K. (2011). Implementing Fair Value Accounting in the Agricultural Sector, The Institute of Chartered Accountants of Scotland, Edinburgh.

Fargher, N. (2001). Management Perceptions of FairValue Accounting for All Financial Instruments, Australian Accounting Review, 11(2), 62-72.

Ferguson, I., \& Leech, J. (2007). Forest Valuation and the AASB 141 Accounting Standards, Forest Product Industry, 70 (2), Institute of Foresters of Australia.

Fisher, R., Motersen, T., \& Webber, D. (2010). Fair Value Accounting in the Agricultural Sector: An Analysis of Financial Statement Preparer's Perception Before and After the Introduction of IAS 41 Agriculture, Afaanz Conference, Christchurch, 4-6 July.

Foo, Y. F (2006). Fair Value Accounting for Local Farm Sector, CPA Australia, ProQuest Information and Leaning Company.

IASC (2001). International Accounting Standard 41: Agriculture, International Accounting Standards Committee, London.

Khera, H. S (1976). The Oil Palm Industry of Malaysia: an Economic Study, Penerbit Universiti Malaya, Kuala Lumpur.

Laux, C., \& Luez, C. (2009). The Crisis of Fair Value Accounting: Making Sense of the Recent Debate, Accounting, Organizations and Society, 826-834.

Lloyd, A., \& Malcolm, B. (1997). Agriculture and the Family Farm in the Economy. in J. Lees (ed.) A legacy under threat? Family Farming in Australia, The University of New England Press, Armidale, NSW.

MAS 8 - Accounting for Pre-Cropping Costs.

MASB (2006). Issue for Comments on Exposure Draft, ED50: Agriculture, Malaysian Accounting Standard Board, Kuala Lumpur.

MPOB (2010). Planters Concerned Over New Accounting Standard, Malaysian Palm Oil Board, the Star, August, 9.

Penman, S. H. (2007). Financial Reporting Quality: is Fair Value a Plus or a Minus?, Accounting and Business Research, Special issue: International Accounting Policy Forum, $33-44$.

Rasiah, R., \& Abdul Rahim, A.S., (2006). Oil Palm Industry: An Economic Study, Kuala Lumpur, University of Malaya Press.

Staltmane, E. G. (2010). Challenges in Accounting the forest - a Latvian Case Study, Ammals of Forest Research, 53(1), 51-58.

Tan, L. T. (2010). Financial Accounting and Reporting in Malaysia, Kuala Lumpur, Professional Advancement Achievement Centre Sdn Bhd, 2 3rd. Edition. 


\section{Macrothink}

Journal of Agricultural Studies

ISSN 2166-0379 2014, Vol. 2, No. 1

Bond Market Association (2002). Explanation and Benefits of Fair Value Accounting, International Swaps \& Derivatties Association (ISDA), Security Industry Association, United States of America.

Thurrun Bhakir, M. I. (2010). Applying IAS 41 in Malaysia, Accountants Today, May 2010.

Tshuguryan A., \& Vedd, R. (2007). Biological Assets Measurement Approaches, Available at: saua.am/fileadmin/user_upload/ASAU/...of.../96-102_02_2009.pdf.

Zain, N. (2009). Issues Clouding Adoption of Malaysia Agriculture Standard in Malaysia, the Edge Malaysia, September 28.

\section{Copyright Disclaimer}

Copyright reserved by the author(s).

This article is an open-access article distributed under the terms and conditions of the Creative Commons Attribution license (http://creativecommons.org/licenses/by/3.0/). 